\title{
UJI EFEKTIVITAS ANTIBAKTERI EKSTRAK ETANOL DAUN GAMAL (Gliricidia sepium) DALAM MENGHAMBAT PERTUMBUHAN BAKTERI Staphylococcus aureus
}

\author{
*)Sainal EdiKamal \\ *)Akademi Farmasi Sandi Karsa Makassar \\ *)Program Studi D-III Farmasi Sandi Karsa Makassar
}

\begin{abstract}
ABSTRAK
Telah dilakukan penelitian dengan tujuan untuk mengetahui Efektivitas Antibakteri Ekstrak Etanol Daun Gamal (Gliricidia sepium) Dalam Menghambat Pertumbuhan Bakteri Staphylococcus aureus. Jenis penelitian ini adalah eksperimental laboratorium menggunakan metode ekstraksi maserasi dengan konsentrasi 15\%, 25\%, 35\% serta kontrol positif Cefadroxil dan kontrol negatif DMSO (Dimethyl sulfoxide) 10\%. Dilakukan replikasi sebanyak 3 kali pada setiap kelompok perlakuan. Hasil penelitian menunjukan adanya zona hambat setelah 1x24 jam dan tidak terdapat perbedaan yang bermakna tiap konsentrasi. Zona hambat terluas terdapat pada konsentrasi $35 \%$ dengan nilai rata-rata 19,76 mm. Dari penelitian ini dapat disimpulkan bahwa ekstrak etanol Daun Gamal (Gliricidia sepium) mempunyai aktivitas antibakteri terhadap pertumbuhan Staphylococcus aureus.
\end{abstract}

Kata Kunci : Uji daya hambat, Ekstrak, Konsentrasi.

\section{PENDAHULUAN}

\section{A. Latar Belakang}

Indonesia merupakan negara dengan keanekaragaman hayati yang melimpah. Hampir segala jenis tumbuhan dapat tumbuh di wilayah negara ini. Sebagian besar sudah dimanfaatkan sejak nenek moyang kita untuk mengobati berbagai penyakit. Indonesia juga mempunyai penduduk yang banyak (sekitar 200 juta lebih) yang sebagian besar penduduknya masih tinggal di pedesaan. Pemanfaatan tanaman sebagai obat pada dasarnya sudah seumur dengan peradaban manusia. Indonesiaa diketahui memiliki keragaman hayati terbesar kedua di dunia setelah Brazil. Dari berbagai penelitian menyebutkan, bahwa dari sebanyak 9.600 spesies tumbuhan diketahui memiliki khasiat obat, namun demikian baru sekitar 200 spesies yang telah dimanfaatkan sebagai bahan baku industri obat tradisional (Kusuma dwi dkk, 2016).

Sampai saat ini telah banyak dilakukan penelitian untuk membuktikan khasiat dari tanaman obat. Namun demikian, percobaan yang dilakukan sampai pada fase penelitian klinik masih sangat sedikit dan umumnya masih bersifat pendahuluan. Oleh karena itu pengalaman empiris yang ditunjang dengan penelitian tanaman obat juga memiliki andil dalam memberikan keyakinan akan khasiat dan keamanan obat tradisional (Kusuma dwi dkk, 2016).

Tanaman gamal memiliki senyawa aktif sekunder yaitu saponin, flavonoid, alkaloid dan tanin yang berfungsi secara aktif dapat menghambat pertumbuhan bakteri pada beberapa varian konsentrasi. Zat aktif yang terkandung pada Daun tanaman gamal dapat diekstrak dengan pelarut etanol (Akharaiyi. F. C., dkk, 2012).

Daun tanaman ini telah dimanfaatkan petani secara luas sebagai insektisida nabati karena mengandung tanin, zat racun dikumerol dan (Hidrogen sianida) HCN yang toksik terhadap serangga. Tanin yang terkandung dalam tanaman gamal juga merupakan zat antiseptik nabati yang mampu bersifat bakteriosidal (Noerbaeti. E., dkk, 2016).

Ekstrak etanol Daun gamal dapat menghambat pertumbuhan bakteri Escherichia coli dan Pseudomonas aeroginosa dengan diameter hambat pada konsentrasi 50\% adalah sebesar $11 \mathrm{~mm}$ dan konsentrasi 100\% sebesar 14 mm pada bakteri Escherichia coli, sedangkan pada bakteri Pseudomonas aeroginosa memiliki daya hambat $15 \mathrm{~mm}$ pada konsentrasi $100 \%$ (Kumar dan Simon, 2016). Penelitian juga menunjukkan bahwa ekstrak Daun gamal dapat menghambat petumbuhan bakteri Gram positif seperti Staphylococcus aureus pada konsentrasi $0,5 \mathrm{mg} / \mathrm{ml}$ dan $0,25 \mathrm{mg} / \mathrm{ml}$ (Nazli. R., dkk, 2011).

Bakteri Staphylococcus aureus adalah bakteri yang pertama kali ditemukan oleh Sir Alexander ogston pada abad ke-19, dia adalah seorang ahli beda Skotlandia dan ahli mikrobiologi amatir. Staphylococcus aureus secara normal merupakan penduduk kulit dan ronggah hidung yang tidak berbahaya. Namun, 
ia memiliki potensi yang patogen yang kuat untuk menyebabkan berbagai infeksi yang didapat dari masyarakat dan rumah sakit. Gangguan toksin, yang menyebabkan spectrum luas sindrom klinis mulai dari infeksi kulit ringan hingga septikimia yang berlebihan (Fetsch Alexander, 2017).

Adapun kandungan dari Daun gamal berdasarkan hasil uji skrining fitokimia yang dilakukan oleh Sonja V.T dan Vandalita, 2017 dapat diketahui bahwa Daun gamal mengandung senyawa kimia steroid, tanin dan saponin. Penelitian lain juga menunjukan adanya metabolit sekunder yakni alkaloid, saponin, steroid, triterpenoid, flavonoid dan fenolik (Kartini ajeng dkk, 2017).

Salah satu tanaman yang terdapat di daerah Kendari adalah Gamal. Berdasarkan hal diatas dan pengalaman empiris, maka perlu diadakan penelitian lebih lanjut untuk menguji apakah benar, Daun gamal (Gliricidia sepium) efektif sebagai antibakteri terhadap bakteri Staphylococcus aureus. Pada penelitian ini menggunakan metode Difusi agar Cakram KIRBY-BAUER.

\section{B. Rumusan Masalah}

Rumusan masalah pada penelitian ini adalah pada konsentrasi berapakah ekstrak etanol Daun gamal (Gliricidia sepium) dapat menghambat bakteri Staphylococcuss aureus?

\section{Tujuan Penelitian}

Tujuan penelitian ini adalah untuk mengetahui efektivitas antibakteri ekstra etanol Daun gamal (Gliricidia sepium) terhadap bakteri Staphylococcuss aureus.

\section{Manfaat Penelitian}

Penelitian ini bermanfaat memberikan informasi kepada masyarakat manfaat bahwa daun gamal sebagai obat tradisional yang dapat digunakan sebagai bahan pengganti obat sintetis, sehingga masyarakat memiliki alternatif dan tidak selalu tergantung pada obat sintetis dan menumbuh kembangkan kesadaran masyarakat tentang penggunaan bahan alam sebagai obat alternatif, sehingga mendorong masyarakat untuk membudidayakan tanaman gamal dan pada akhirnya dapat menekan pengeluaran yang lebih banyak untuk pembelian obat.

\section{METODE PENELITIAN}

\section{A. Jenis Penelitian}

Jenis penelitian ini bersifat eksperimental laboratorium dengan metode difusi agar cakram KIRBY-BAUER.

\section{B. Waktu Dan Tempat Penelitian}

Penelitiana ini dilakukan pada Maret 2020 di laboratorium Mikrobiologi Sandi karsa Makassar.

\section{Populasi dan Sampel}

Pada penelitian ini sampel yang digunakan yakni Daun gamal (Gliricidia sepium), yang diperoleh dari Kendari Sulawesi Tenggara.

\section{Alat dan Bahan}

Alat yang digunakan yaitu Autoklaf (Medical Oxygen Gauge), Batang pengaduk, Botol pengencer, Cawan petri (pirex), Erlenmeyer (Pirex), Gelas kimia (Approx), Gelas ukur (Pirex), Inkubator (Wina Instrumenty), Jangka sorong (Tricle Brand), Laminar Air Flow (Heles), Lampu spiritus, Ose, Penangas air, Pinset, Pipet tetes, Rak tabung, Sendok tanduk, Spoit, Tabung reaksi (Pirex), Timbangan analitik (CHQ).

Bahan yang digunakan yaitu Air suling (H2O), Alkohol 96\%, Aluminium foil, Biakan murni Staphylococcus aureus, DMSO (Dimethyl sulfoxide), Ekstrak etanol Daun gamal (Gliricidia sepium) sebagai sampel, Larutan $\mathrm{NaCl}$ 0,9\%, Medium NA (Nutrient Agar), Paper disk, Plastik warp, Cefadroxil, Suspense bakteri.

\section{E. Metode Penelitian}

1. Penyiapan Alat

Alat-alat yang digunakan disterilkan dan dicuci terlebih dahulu dengan detergen kemudian dibilas dengan air bersih, selanjutnya dibilas menggunakan Alkohol $70 \%$, kemudian dicuci hingga bersih dengan air suling lalu dikeringkan dengan posisi terbalik. Setelah itu disterilkan dengan autoklaf pada suhu 121 oC selama 15 menit dengan tekanan $2 \mathrm{~atm}$.

2. Penyiapan Bahan

a. Pembuatan sampel ekstrak etanol Daun Gamal (Gliricidia sepium)

Sampel yang digunakan adalah Daun Gamal (Gliricidia sepium) yang diambil pada pukul 7-10 pagi, dan diolah menjadi simplisia dan diekstraksi menggunakan metode maserasi, diuapkan sehingga menjadi ekstrak kental. Lalu dilakukan uji bebas etanol dengan mengambil beberapa sampel dan dimasukkan ke dalam tabung reaksi dan diberi 1 tetes asam asetat dan asam sulfat. Jika tidak tercium bau khas pisang ambon berarti tidak terdapat kadar etanol.

b. Pembuatan konsentrasi ekstrak etanol Daun Gamal (Gliricidia sepium) 
Untuk membuat konsentrasi ekstrak etanol Daun Gamal maka ditimbang masing-masing sampel yakni 15 gram, 25 gram, dan 35 gram. Kemudian dilarutkan dengan DMSO $10 \%$ dan diaduk sampai benar-benar homogen.

c. Pembuatan MediumNutrien Agar (NA)

Ditimbang medium NA (Nutrient Agar) sebanyak 2,8 gram, di masukkan kedalam erlenmeyer kemudian dilarutkan dengan air suling hingga $100 \mathrm{ml}$. Setelah itu disterilkan pada autoklaf selama 15 menit pada suhu $121 \mathrm{oC}$ dengan tekanan 2 atm.

d. Peremajaan Bakteri

Staphylococcus aureus yang berasal dari biakan murni sebagai sampel, diambil sebanyak satu ose bulat lalu diinokulasikan dengan cara digores pada medium NA (Nutrient Agar) miring. Kultur bakteri dari masing-masing agar miring diinkubasi pada suhu $37 \mathrm{oC}$ selama 24 jam.

e. Pembuatan Suspensi Bakteri

Staphylococcus aureus yang merupakan hasil dari peremajaan dari medium NA (Nutrient Agar) miring diencerkan dengan menggunakan $\mathrm{NaCl}$ $0,9 \%$ sebanyak $10 \mathrm{ml}$.

f. Pembuatan Larutan Pembanding

Larutan kontrol positif menggunakan Cefadroxil $500 \mathrm{mg}$ yang dilarutkan dalam DMSO 10\% dan untuk kontrol negatif menggunakan DMSO $10 \%$.

g. Pengujian daya hambat ekstrak etanol Daun Gamal (Gliricidia sepium)

Dispoit bakteri sebanyak $1 \mathrm{ml}$ lalu dimasukkan kedalam cawan petri, setelah itu dimasukkan medium NA (Nutrient Agar) sebanyak $20 \mathrm{ml}$ dan dihomogenkan dengan cara membentuk angka delapan. Disiapkan 5 paper disk, 3 paper disk dimasukkan kedalam konsentrasi ekstrak etanol dengan masing-masing konsentrasi yang dibuat, yaitu $15 \%, 25 \%$ dan $35 \%$. 1 paper disk dimasukkan kedalam DMSO 10\% (untuk kontrol negatif) dan 1 paper disk lagi dimasukkan kedalam larutan Cefadroxil (untuk kontrol positif) di rendam beberapa menit kemudian diambil menggunakan pinset steril dan ditempatkan 4 paper disk secara diagonal pada permukaan medium tersebut dan 1 paper disk berada ditengah. Kemudian cawan petri tersebut diberi penandaan dan dibungkus dengan plastik wrap. Diinkubasi pada suhu 37 oC selama $1 \times 24$ jam. h. Pengamatan dan Pengukuran Diameter Hambatan

Pengamatan dan pengukuran diameter hambatan dilakukan dengan menggunakan jangka sorong setelah diinkubasi selama 1x24 jam.

\section{F. Analisis Data}

Data yang telah diperoleh kemudian dikumpul dan diolah dengan menggunakan spss.

\section{HASIL DAN PEMBAHASAN}

\section{A. Hasil Penelitian}

Hasil pengujian uji daya hambat ektrak etanol Daun Gamal (Gliricidia sepium) terhadap pertumbuhan Staphylococcus aureus dapat dilihat pada tabel berikut.

Tabel I. Hasil pengamatan uji daya hambat ekstrak etanol Daun Gamal (Gliricidia sepium) terhadap Staphylococcus aureus

\begin{tabular}{|c|c|c|c|c|c|}
\hline \multirow[t]{3}{*}{ Replikasi } & \multicolumn{5}{|c|}{ Diameter zona hambat (mm) } \\
\hline & \multicolumn{4}{|c|}{ Konsentrasi } & Kontrol \\
\hline & $15 \%$ & $25 \%$ & $35 \%$ & Kontrol (-) & Kontrol (+) \\
\hline $\mathrm{I}$ & 17.67 & 17.87 & 18.23 & 0 & 33.9 \\
\hline II & 16.37 & 17.47 & 19.4 & 0 & 38.37 \\
\hline III & 15.53 & 18.37 & 21.67 & 0 & 31.63 \\
\hline Jumlah & 49.57 & 53.71 & 59.3 & 0 & 103.9 \\
\hline Rata-rata & 16.52333 & 17.90333 & 19.76667 & 0 & 34.63333 \\
\hline
\end{tabular}

Data primer 2020

Table 1 diperoleh dari pengukuran 3 arah, yakni vertical, horizontal dan diagonal.

\section{B. Pembahasan}

Penelitian mengenai uji daya hambat ekstrak etanol Daun Gamal (Gliricidia sepium) terhadap Staphylococcus aureus ini mendapatkan hasil bahwa ekstrak etanol Daun Gamal mempunyai daya hambat terhadap pertumbuhan Staphylococcus aureus. Hal ini terbukti dengan terdapatnya diameter zona hambat disekitar paper disk.

Selain itu pada penelitian ini digunakan pula dua kontrol, yakni kontrol negatif dan kontrol positif, dimana kontrol positif yang digunakan yakni Cefadroxil. Cefadroxil merupakan golongan antibiotik Sefalosporin yang memiliki mekanisme kerja menghambat pembentukan dinding sel, sehingga bakteri tidak dapat bertahan hidup. Salah satu bakteri yang dapat dihambat oleh antibiotik ini adalah Staphylococcus aureus, dimana bakteri ini merupakan bakteri penyebab infeksi pada kulit.

Untuk pengukuran diameter daya hambat, pada ekstrak etanol Daun Gamal pada konsentrasi $15 \%$ didapatkan nilai rata-rata $16,52 \mathrm{~mm}$, konsentrasi $25 \%$ didapatkan nilai 
rata-rata $17,90 \mathrm{~mm}, \quad$ konsentrasi $35 \%$ didapatkan nilai rata-rata $19,76 \mathrm{~mm}$, kontrol positif Cefadroxil didapatkan nilai rata-rata $34,63 \mathrm{~mm}$ dan kontrol negative menggunakan DMSO (Dimethyl sulfoxide) 10\% ialah $0 \mathrm{~mm}$ atau tidak memiliki zona hambat. Hasil ini menunjukan bahwa semakin besar konsentrasi ekstrak etanol Daun Gamal maka semakin besar zona hambat yang diperoleh, walaupun demikian dapat dilihat bahwa zona hambat kontrol positif masih lebih besar jika dibandingkan dengan zona hambat pada konsentrasi $35 \%$.

Dengan adanya hasil penelitian yang telah dilakukan dapat dilihat bahwa walaupun dengan konsentrasi yang rendah, ekstrak etanol daun gamal sudah dapat menghambat bakteri Staphylococcus aureus, jika dibandingkan dengan penelitian sebelumnya, yakni penelitian yang dilakukan oleh Budi, N. L., dkk pada tahun 2018 dengan konsentrasi yang lebih tinggi yakni $25 \%$ dan $50 \%$.

Untuk mengetahui ada tidaknya pengaruh perbedaan konsentrasi ekstrak etanol Daun Gamal terhadap diameter daya hambat bakteri uji antar kelompok maka digunakan uji parametrik one way ANOVA, tetapi sebelum dilakukan analisa data dengan uji one way ANOVA, maka data terlebih dahulu harus dilakukan uji normalitas dan homogenitas data. Dari hasil uji normalitas mengunakan ShapiroWilk (data dapat dilihat pada lampiran tabel 5) didapatkan nilai signifikan untuk masingmasing data $(\rho>0,05)$ yang artinya dataterdistribusi normal, setelah itu dilakukan uji homogenitas menggunakn uji Levene (data dapat dilihat pada lampiran tabel 6) didapatkan nilai signifikan untuk daya hambat terhadap Staphylococcus aureus $\rho=0,684 \quad(\rho>0,05)$ dengan hasil tersebut maka dapat dilakukan pengujian lebih lanjut dengan mengguakan uji one way ANOVA.

Berdasarkan uji one way ANOVA (dapat dilihat pada lampiran tabel 7) diketahui bahwa pada variabel terikat daya hambat Stahpylococcus aureus nilai tidak signifikan $\rho=0,980 \quad(\rho<0,05)$ yang berarti tidak terdapat perbedaan yang bermakna pada setiap konsentrasi ekstrak etanol Daun Gamal terhadap daya hambat Staphylococcus aureus yang dihasilkan pada media agar.

Setelah mengetahui bahwa tidak ada perbedaan yang bermakna pada daya hambat bakteri Stahpylococcus aureus yang dihasilkan pada media nutrient agar dengan 3 replikasi akibat pengaruh perlakuan dari ke-3 variasi konsentrasi ekstrak Daun Gamal mana saja yang berbeda dan tidak berbeda pengaruhnya terhadap daya hambat Stahpylococcus aureus dilakukan uji LSD (data dapat dilihat pada lampiran 8) diperoleh bahwa tidak terdapat perbedaan yang bermakna tiap konsentrasi atau tidak ada pengaruh perlakuan konsentrasi ekstrak etanol Daun Gamal terhadap pertumbuhan Stahpylococcus aureus dengan rata-rata pada konsentrasi 15\% didapatkan nilai rata-rata $16,52 \mathrm{~mm}$, konsentrasi $25 \%$ didapatkan nilai rata-rata $17,90 \mathrm{~mm}$, konsentrasi 35\% didapatkan nilai rata-rata 19, $76 \mathrm{~mm}$. Sedangkan pada kontrol positif dan negative terdapat perbedaan yang bermakna atau ada pengaruh perlakuan terhadap konsentrasi.

\section{PENUTUP}

\section{A. Kesimpulan}

Berdasarkan analisis statistik dan pembahasan terhadap hasil penelitian diperoleh kesimpulan bahwa tidak terdapat perbedaan yang bermakna tiap konsentrasi, dimana daya hambat terluas terdapat pada konsentrasi 35\% dengan nilai rata-rata $19,76 \mathrm{~mm}$. Dari semua konsentrasi ekstrak etanol Daun Gamal (Gliricidia sepium) mempunyai aktivitas antibakteri terhadap Staphylococcus aureus.

\section{B. Saran}

Disarankan untuk perlu dilakukan uji lanjutan seperti uji secara toksisitas dan uji klinis agar tanaman Gamal khususnya daun dapat dimanfaatkan secara maksimal, serta perlu pula dilakukan penelitian lebih lanjut dengan menggunakan jarak konsentrasi yang lebih luas, agar zona daya hambat yang diperoleh lebih signifikan.

\section{DAFTAR PUSTAKA}

Akharaiyi. F. C., dkk. 2012. Antibacterial, phytochemical and antioxigdant activity of the leaf extracts or gliricidia sepium and spatodea campanulata. World applied sciences jurnal. 16(4), pp. 523-536

Budi, N. L., dkk. 2018. Aktivitas antibakteri ekstak etanol daun gamal (Gliricidia sepium) pada berbagai konsentrasi terhadap pertumbuhan bakteri Streptococcus mutans secara invitro. Denpasar; Jurusan analisis kesehatan, politeknik kesehatan kemenkes Denpasar, Indonesia. Issn 2548-5695

Dalimarta, setiawan dan Felix adria. 2013. Herbal tumpas penyakit. Jakarta; Penebar swadaya

Fetsch Alexander. 2017. Staphylococcus aureus. London. Academy Press 
Firdaus, Muhammad dkk. 2013. Tanaman bakau biologi dan bioaktivasi. Malang; UB Press

Kartini. A., dkk. 2017. Uji Fitokimia dan uji toksisitas ektra daun gamal (Gliricidia sepium) sebagai insektisida nabati. Sarinda; Jurnal Mulawarman

Kementrian pertanian direktorat jenderal peternakan dan kesehatan hewan, 2009. Keunggulan gamal sebagai pakan ternak. Sembawa; Balai pembibitan ternak unggul sapi dwiguna dan ayam sembawa

Kusuma dwi dkk. 2016. Toga Indonesia. Surabaya; airlangga university press

Kusnadi joni. 2018. Pengawet untuk makanan. Malang; UB press

Mukhraini. 2014. Jurnal Kesehatan Ekstraksi, Pemisahan Senyawa Dan Indentifikasi Senyawa Aktif. Makassar; Universitas Islam Negri Alauddin

Murwani sri., dkk. 2017. Penyakit bakterial pada ternak hewan besar dan unggas. Malang; UB press

N. A. SH winata dkk. 2012. Pertumbuhan dan produksi hijauan gamal (Gliricidia sepium) dengan berbagai dosis pupuk organik cair. Semarang; Fakultas peternakan diponegoro semarang

Najib ahmad. 2018. Ekstraksi senyawa bahan alam. Sleman; Deepublish

Nazli. R., dkk. Antimicrobial property of Gliricidia sepium plant. Journal of agriculture. 24(1). Pp. 51-55. Available

Noerbaeti. E., dkk. 2016. Potensi ekstrak daun gamal (Gliricidia sepium) sebagai antibakteri Vibrio sp dan Flexibacter maritimum. Journal teknoogi budidaya laut. 6, pp. 43-49

Panji emma. 2012. Sehat cara al-quran dan hadis. Jakarta; Hikma (PT. mizan publika)

Pratiwi S. T. 2008. Mikrobiologi Farmasi. Jakarta; Erlangga

Pudjiastuti pratiwi. 2010. Alkaloid dan non alkaloid. Surabaya; Airlangga University Press
Sonja V. T dkk. 2017. Analisis kandungan kimia daun gamal (Gliricidia sepium) dan kulit buah nanas (Ananas comosus L) sebagai bahan baku pestisida nabati. ISBN 978 602-50942-0-0

Suharman. 2018. Gambir, peluang pasar budidaya dan pengolahannya. Sleman; deepublish

Yanuhar U. 2016. Mikroalga Laut. Malang; UB press 